\title{
ANALISIS KINERJA KEUANGAN PADA PT. SEMEN INDONESIA (PERSERO), TBK. YANG TERDAFTAR DI BURSA EFEK INDONESIA
}

\author{
Anita Erawati, Suprianto, Ade Rahmat Ayu \\ Alumni Sekolah Tinggi Ilmu Manajemen Sukma \\ Program studi Manajemen, Sekolah Tinggi Ilmu Manajemen \\ supriantosu80@gmail.com, aderahma924@gmail.com
}

\begin{abstract}
Perkembangan posisi keuangan mempunyai arti yang sangat penting bagi perusahaan untuk menilai kinerjanya. Pemahaman mengenai posisi keuangan bisa menjadikan dasar untuk mengevaluasi apakah kondisi keuangan perusahaan tersebut sehat atau tidak, mengingat sudah banyak isu permasalahan yang menyebabkan perusahaan yang akhirnya di liquidasi karena faktor keuangan yang tidak sehat. Laporan keuangan merupakan salah satu alat yang dipakai untuk mengetahui kinerja keuangan perusahaan yang disusun dalam setiap akhir periode yang berisi tentang pertanggungjawaban keuangan secara keseluruhan. Laporan keuangan ini memberikan gambaran atas keuangan perusahaan dalam satu periode akuntansi yang terdiri dari laporan posisi keuangan, laporan laba rugi komprehensif, laporan perubahan ekuitas pemegang saham, laporan arus kas, dan catatan atas laporan keuangan. Masalah keuangan merupakan salah satu masalah yang sangat vital bagi perusahaan dalam perkembangan bisnis disemua perusahaan. Kemampuan perusahaan dalam menghasilkan keuntungan adalah kunci keberhasilan perusahaan untuk dapat dikatakan mempunyai kinerja perusahaan yang baik, karena keuntungan merupakan komponen laporan keuangan yang digunakan sebagai alat untuk menilai baik tidaknya kinerja perusahaan.
\end{abstract}

Keywords: analisis kinerja, bursa efek

\section{PENDAHULUAN}

Penelitian yang dilakukan Budiono (2013) yang berjudul Evaliasi Kinerja Keuangan PT. PLN (Persero) Periode 2010-2012 menyimpulkan bahwa Kinerja Keuangan PT. PLN (Persero) secara keseluruhan menunjukan nilai yang kurang sehat. Penelitian oleh Nurindra (2013) yang berjudul Analisis Kinerja Keuangan PT. Wijaya Karya Tbk Tahun 2007-2011 menyimpulkan bahwa kinerja keuangan PT Wijaya Karya (persero) Tbk dalam kurun waktu lima tahun terakhir dinyatakan sehat. Kaunang (2013) yang berjudul Analisis Kinerja Keuangan Perusahaan Pada PT. Cipta Daya Nusantara Manado menyimpulkan bahwa secara umum berdasarkan rasio keuangan yaitu posisi likuiditas dalam keadaan baik dalam hal perhitungan current ratio dan quick ratio, akan tetapi pada cash ratio perusahaan masih kurang dimana uang kas yang dimilki perusahaan belum mampu melunasi utang perusahaan. Rasio solvabilitas dapat dilihat bahwa hanya debt to asset ratio yang cukup meningkat, dan untuk perhitungan debt to equity ratio dan LTDtER mengalami penurunan. Penelitian yang telah dilakukan Ningrum (2014) yang berjudul Pengujian Aspek Keuangan pada PT. 
Kereta Api (Persero) DAOP 4 Semarang menyimpulkan bahwa aspek keuangan mengalami peningkatan dari tahun sebelumnya, namun masih torgolong kategori kurang sehat.

\section{Perumusan Masalah}

Berdasarkan latar belakang penelitian diatas, maka rumusan masalah penelitian adalah: Bagaimanakah Kinerja Keuangan PT. Semen Indonesia (Persero) Tbk. yang terdaftar di Bursa Efek Indonesia ?

\section{Batasan Masalah}

Penelitian ini hanya dibatasi pada PT. Semen Indonesia (Persero) Tbk. yang terdaftar di Bursa Efek Indonesia pada laporan keuangan tahun 2013-2015, berdasarkan rasio profitabilitas.

\section{Tujuan Penelitian}

Adapun tujuan penelitian ini adalah untuk mengetahui kinerja keuangan PT. Semen Indonesia (Persero) Tbk. yang terdaftar di Bursa Efek Indonesia berdasar rasio profitabilitas.

\section{Manfaat Penelitian}

Hasil dari penelitian ini di harapkan dapat memberikan manfaat pada beberapa pihak, yaitu:

1. Bagi peneliti, sebagai penambah pemahaman, ilmu pengetahuan dan wawasan mengenai analisis kinerja keuangan khususnya mengenai profitabilitas.

2. Bagi perusahaan, sebagai bahan masukan dan pertimbangan bagi perusahaan dalam meningkatkan kinerja keuangan, khususnya mengenai kemampuan laba (profitabilitas) perusahaan.

3. Bagi STIM Sukma, sebagai tambahan hasil penelitian yang dapat digunakan sebagai bahan rujukan dan dikembangkan lebih lanjut.

4. Bagi peneliti selanjutnya, sebagai bahan referensi khususnya yang berkaitan dengan kinerja keuangan. 


\section{METODE PENELITIAN}

\section{Jenis dan Sumber Data}

Data yang digunakan dalam penelitian ini adalah data sekunder dalam bentuk skala numerik. Sumber data diperoleh secara tidak langsung, yang berupa catatan laporan keuangan perusahaan maupun laporan historis yang telah tersimpan dan dipublikasikan. Data yang digunakan dalam penelitian ini berupa laporan keuangan perusahaan manufaktur yang terdaftar di BEI, yang didapatkan dari situs www.idx.co.id selama periode 2013-2015.

\section{Metode Pengumpulan Data}

Metode pengumpulan data dalam penelitian ini menggunakan metode studi dokumentasi. Studi dokumentasi ini diperoleh dengan cara mengumpulkan berbagai dokumen-dokumen yang diperoleh dari perusahaan seperti laporan keuangan yang terdiri dari neraca dan laporan laba rugi, struktur organisasi perusahaan, buku, internet, serta jurnal-jurnal penelitian yang relevan.

\section{Metode Analisis Data}

Dalam penelitian ini, metode yang digunakan adalah metode deskriptif Kuantitatif. Sedangkan teknik analisis yang digunakan dalam penelitian ini adalah analisis rasio profitabilitas. Penelitian ini menggambarkan data yang berkaitan dengan penelitian yang berupa tabel-tabel dengan diberi penjelasan berkaitan dengan data tersebut.

\section{HASIL DAN PEMBAHASAN}

Teknik analisis yang dipakai dalam penelitian ini adalah rasio profitabilitas. Analisis profitabilitas disebut juga analisis rentabilitas yaitu analisis yang menggambarkan kemampuan perusahaan mendapatkan laba.

Rasio-rasio yang digunakan dalam analisis profitabilitas adalah:

\section{a. Gross Profit Margin}

Tabel 1

Gross Profit Margin

PT. Semen Indonesia (Persero), Tbk.

\begin{tabular}{|c|c|c|c|c|}
\hline Tahun & Penjualan & Hpp & Laba Kotor & GPM (\%) \\
\hline 2013 & 24.501 .240 .780 & 13.557 .146 .834 & 10.944 .093 .946 & 0.45 \\
\hline 2014 & 26.987 .035 .135 & 15.408 .157 .860 & 11.578 .877 .275 & 0.43 \\
\hline 2015 & 26.948 .004 .471 & 16.302 .008 .098 & 10.645 .996 .373 & 0.40 \\
\hline
\end{tabular}


Pada tahun 2013, gross profit margin PT. Semen Indonesia (Persero), Tbk sebesar $0.45 \%$. Hal ini berarti perusahaan mendapat laba kotor yang nilainya $0.45 \%$ dari total penjualan. Semakin besar nilai rasionya, maka semakin besar profitabilitas yang dimiliki oleh perusahaan.

Pada tahun 2014, gross profit margin mengalami penurunan dari $0.45 \%$ pada tahun 2013 menjadi $0.43 \%$ pada tahun 2014 . Hal ini berarti perusahaan mendapat laba kotor yang nilainya $0.43 \%$ dari total penjualan yang mengalami penurunan.

Pada tahun 2015, gross profit margin mengalami penurunan lagi yaitu dari $0.43 \%$ pada tahun 2014 menjadi $0.40 \%$ pada tahun 2015. Hal ini berarti perusahaan mendapat laba kotor yang nilainya $0.40 \%$ dari total penjualan yang mengalami penurunan.

\section{b. Net Profit Margin}

Tabel 2

Net Profit Margin

PT. Semen Indonesia (Persero), Tbk.

\begin{tabular}{|c|c|c|c|}
\hline Tahun & Laba Bersih & Penjualan & NPM (\%) \\
\hline 2013 & 5.354 .298 .521 & 24.501 .240 .780 & 21.8 \\
\hline 2014 & 5.567 .659 .839 & 26.987 .035 .135 & 20.6 \\
\hline 2015 & 4.525 .441 .038 & 26.948 .004 .471 & 16.7 \\
\hline
\end{tabular}

Pada tahun 2013, net profit margin PT. Semen Indonesia (Persero), Tbk sebesar 21.8\%. Hal ini berarti perusahaan mendapat laba bersih yang nilainya $21.8 \%$ dari total penjualan. Semakin besar nilai rasionya, maka semakin besar profitabiitas yang dimiliki oleh perusahaan. Artinya semakin besar laba bersih yang diperoleh perusahaan.

Pada tahun 2014, net profit margin mengalami penurunan dari $21.8 \%$ pada tahun 2013 menjadi $20.6 \%$ pada tahun 2014 . Hal ini berarti perusahaan mendapat laba bersih yang nilainya $20.6 \%$ dari total penjualan yang mengalami penurunan.

Pada tahun 2015, net profit margin mengalami penurunan lagi dari 20.6\% pada tahun 2014 menjadi $16.7 \%$ pada tahun 2015 . Hal ini berarti perusahaan mendapat laba bersih yang nilainya $16.7 \%$ dari total penjualan yang mengalami penurunan. 
Tabel 3

Return On Asset

PT. Semen Indonesia (Persero), Tbk.

\begin{tabular}{|c|c|c|c|}
\hline Tahun & Laba Bersih & Total Asset & ROA (\%) \\
\hline 2013 & 5.354 .298 .521 & 30.792 .884 .092 & 17.3 \\
\hline 2014 & 5.567 .659 .839 & 34.331 .674 .737 & 16.2 \\
\hline 2015 & 4.525 .441 .038 & 38.153 .118 .932 & 11.8 \\
\hline
\end{tabular}

Pada tahun 2013, return on asset PT. Semen Indonesia (Persero), Tbk. sebesar 17.3\%. Semakin tinggi persentasi rasio ini semakin baik penggunaan asset secara efisien untuk memperoleh keuntungan bersih dalam kegiatan operasional perusahaan.

Pada tahun 2014, return on asset mengalami penurunan dari $17.3 \%$ pada tahun 2013 menjadi $16.2 \%$ pada tahun 2014 . Hal ini berarti menurunnya penggunaan aktiva secara efisien.

Pada tahun 2015, return on asset mengalami penurunan dari $16.2 \%$ pada tahun 2014 menjadi $11.8 \%$ pada tahun 2015 . Hal ini berarti penggunaan aktiva yang dipakai kurang produktif bagi perusahaan.

\section{d. Return On Equity (ROE)}

Tabel 4

Return On Equity

PT. Semen Indonesia (Persero), Tbk.

\begin{tabular}{|c|c|c|c|}
\hline Tahun & Laba Bersih & Total Equity & ROE (\%) \\
\hline 2013 & 5.354 .298 .521 & 21.803 .975 .875 & 24.5 \\
\hline 2014 & 5.567 .659 .839 & 25.004 .930 .004 & 22.2 \\
\hline 2015 & 4.525 .441 .038 & 27.440 .798 .401 & 16.4 \\
\hline
\end{tabular}

Pada tahun 2013, return on equity PT. Semen Indonesia (Persero), Tbk. sebesar 24.5\%. Dengan kata lain rasio pengembalian atas investasi pemilik perusahaan sebesar $24.5 \%$. Semakin tinggi persentase yang diperoleh perusahaan menunjukkan semakin tinggi pengelolaan modal prusahaan dalam mendapatkan laba atas modal tersebut.

Pada tahun 2014, return on asset mengalami penurunan dari $24.5 \%$ pada tahun 2013 menjadi $22.2 \%$ pada tahun 2014 . Hal ini berarti keuntungan yang menjadi hak pemilik modal sendiri adalah sebesar $22.2 \%$. 
Pada tahun 2015, gross profit margin mengalami penurunan drastic dari $22.2 \%$ pada tahun 2014 menjadi 16.4\% pada tahun 2015. Hal ini disebabkan berkurangnya pendapatan perusahaan yang mempengaruhi modal pemilik.

\section{KESIMPULAN}

Berdasarkan hasil penelitian data yang telah penulis analisis dengan menggunakan rasio profitabilitas, maka dapat disimpulkan :

Secara umum kinerja keuangan perusahaan berdasarkan analisis profitabilitasnya belum efisien dan kurang baik. Ini disebabkan karena tingkat profitabilitasnya tidak stabil sehingga mengalami penurunan dalam tiga tahun berturut-turut dan masih berada di bawah rata-rata industri.

Kinerja keuangan perusahaan berdasarkan Gross Profit Margin dari tahun 2013 hingga 2015 mengalami penurunan yaitu mulai dari $0.45 \%$ pada tahun 2013 turun menjadi $0.43 \%$ pada tahun 2014 dan $0.40 \%$ pada tahun 2015. Net Profit Margin juga mengalami penurunan mulai tahun 2013 hingga 2015 yaitu $21.8 \%$ pada tahun 2013 , menjadi $20.6 \%$ pada tahun 2014, hingga $16.7 \%$ pada tahun 2015 . Return On Asset mengalami penurunan pada tahun 2013 sebesar 17.3\%, pada tahun 2014 sebesar 16.2\%, dan pada tahun 2015 sebesar 11.8\%. dan Return On Equity juga mengalami penurunan selama tiga tahun berturut-turut yaitu $24.5 \%$ pada tahun 2013 , menurun mejadi $22.2 \%$ pada tahun 2014 , hingga $16.4 \%$ pada tahun 2015 . 


\section{REFERENCES}

Ariefiansyah dan Miyosi. (2012). Membuat Laporan Keuangan. Cetakan Pertama. Jakarta Tumur. Laskar Aksara.

Budiono, F.R.P. (2013). Evaliasi Kinerja Keuangan PT. PLN (Persero) Periode 2010-2012. http://eprints.dinus.ac.id/8706/1/jurnal_13246.pdf

Fahmi, I. (2012). Analisis Laporan Keuangan. Bandung: Penerbit Alfabeta.

Ikatan Akuntan Indonesia. (2015). Standar Akuntansi Keuangan per Efektif 1 Januari 2015.

Kasmir. (2012). Analisis Laporan Keuangan. Jakarta: Raja Grafindo..

Kaunang, S.A. (2013). Analisis Kinerja Keuangan Perusahaan pada PT. Cipta Daya Nusantara Manado. Jurnal EMBA, Vol. 1(4) : 1993-2003.

Munawir, S. (2012). Analisis Laporan Keuangan. Yogyakarta: Liberty.

Ningrum, D. (2014). Pengujian Aspek Keuangan Pada PT. Kereta Api (Persero) DAOP 4 Semarang pada tahun 2011-2012 Menurut Surat Keputusan Menteri Negara BUMN Nomor : Kep100/MBU/2002. http://eprints.dinus.ac.id/8707/1/jurnal_13247.pdf

Nurindra, D.A. (2013) Analisis Kinerja Keuangan PT Wijaya Karya Tbk Tahun 2007-2011. Jurnal Akuntansi Unesa, Vol. 1(3) : 1-24.

Rudianto. (2013). Akuntansi Manajemen: Informasi untuk Pengambilan Keputusan Strategis. Jakarta: Erlangga.

Subramanyam. (2012). Analisis Laporan Keuangan. Jakarta: Salemba Empat.

Sucipta, I.K.A., I.W. Suwendra dan W. Cipta. (2015). Analisis Kinerja Keuangan Perusahaan dengan Menggunakan Rasio Keuangan dan Metode EVA (Economic Value Added) pada Perusahaan LQ 45 yang terdaftar di BEI. E-Journal Bisma Universitas Pendidikan Ganesha, Vol. 3 : 1-10.

Sutrisno. (2013). Manajemen Keuangan Teori, Konsep dan Aplikasi. Yogyakarta: UII.

Wardayani. (2015). ANALISIS KINERJA KEUANGAN PADA PT. SIAR HARAMAIN INT. WISATA MEDAN. Jurnal Bis-A: Jurnal Bisnis Administrasi, 4(2), 14-24.

Wardayani. (2013). Pengaruh Pengetahuan Dewan Tentang Anggaran, Partisipasi Masyarakat dan Transparansi Kebijakan Publik terhadap Kinerja DPRD dalam Pengawasan Keua. Jurnal BIS-A Politeknik LP3i Medan, 2, 35-45.

Wardayani. (2012). ANALISIS PERBANDINGAN KINERJA KEUANGAN DITINJAU DARI SEGI PROFITABILITAS PADA PT. INDOFOOD CBP SUKSES MAKMUR. Jurnal Riset Akuntansi, 1, 40-52. 